\title{
Concept of Smart City Governance in Makassar City
}

\author{
Muhlis Madani \\ Public Administration Department \\ Muhammadiyah University of Makassar \\ Makassar, Indonesia
}

\author{
Nasrulhaq \\ Public Administration Department \\ Muhammadiyah University of Makassar \\ Makassar, Indonesia \\ nasrulhaq@unismuh.ac.id
}

\begin{abstract}
This research aims to know the core concept of smart city governance in Makassar City. Smart city is one of new program in Makassar City. Its brand is sombere and smart city. However, practice of smart city have weakness and treatness in governance aspects. This research used qualitative method with case study approach in Makassar City. Data collecting technique are in-dept interview, observation, documentation and visual materi. Based on the result of the research, core concept of smart governance is sociotechnical. The unification are social value and technological aplication. Items in smart governance concept are public service, management of bureucratic, and efficiency of public policy.
\end{abstract}

Keywords: smart city; governance; Makassar

\section{INTRODUCTION}

Currently, smart city becomes one of the policies as well as the flagship program of the government of Makassar City. In this program, the government of Makassar City carries the theme of Sombere' and Smart City Makassar (Makassar city smart and friendly). Sombere' is interpreted as heartware and smart city is interpreted as hardware and software. In general, the idea of smart city in Makassar City refers to sociotechnical perspective. This perspective understands that smart cities not only defined in the use of information and technology tools but also the use of information and technology artifacts in the wider social and organizational context [1]. The combination of cultural values and application of technology is a concept that is still scarce in Indonesia. Smart city governance program in Makassar City becomes an important study for further study.

Parties involved in the Smart City Makassar program are very widely. Initiation and implementation of the Smart City Program involves all the Regional Government Work Units (SKPD) of the Makassar City Government, the Ministry of Communication and Information of the Republic of Indonesia (Menkominfo), several State and Private Universities in Makassar City, national companies concerning in developing information and technology tools and community groups. The large number of parties involved in intelligent city programs with different forms and levels becomes very interesting in the study of governance models. The phenomena are categorized as multilevel governance. Multilevel governance has become an integral part of the globalization era. The modern era based on IT (information and technology) demands the development of an area by involving government, private and community elements from different levels to interact with each other. In short, the concept of smart city governance applied in Makassar City has its own characteristics that distinguish it from other regions in Indonesia.

In a book titled Megacities: Urban Form, Governance, and Sustainability edited by [2] explain that research and assessment of urban forms has become the latest topic in recent years. According to them, urban model have many phenomena because each city has historical experience, governance system, level of development and different geographical conditions, both in developed and developing countries. Smart city-related research leads to the improvement and development of modern urban management [1], [3], [4], [5], [6].

The main focus of the concept of smart city governance is understood by experts differently, some link it to economic, environment, social and technological issues. In this study, researchers focused on smart city related to social and technological issues. This is based on [3] writing which confirms that the concept of smart city must be understood as technology learning (systems integration and testing flexibility) and social attachment (actors' coalition formation, socio-political structure and solution integration) combined into sociotechnical terminology. Furthermore, Carvalho's view is reinforced by [1] which states the idea of smart city should be viewed as sociotechnical. The sociotechnical approach reflects the social and technical aspects of an urban. According to them, these two aspects are closely related to the concept of smart city. Therefore, researchers refer to the views of Carvalho and Goodspeed in assessing the existing phenomenon.

\section{RESEARCH METHODS}

This research uses qualitative research method. Qualitative research is intended to explore and understand the meaning of

Corresponding author: Nasrulhaq 
the problems of smart city governance. Qualitative research focuses on the individual meaning and complexity of the problems that occur in Makassar. Researchers use qualitative methods because the researchers closer to the informant in digging information for the latest information. The type of approach used is case study. The analysis unit is the social and technological concept in smart city governance in Makassar City. Sources of research data consisted of three informants (primary), events (secondary), documents (secondary) and audio-visual material (secondary). The technique used in determining primary data source or informant is purposive sample (sample determination technique with certain consideration). All parties directly involved in the program remain the target of informants.

Data collected using 4 techniques that support each other in order to sharpen data analysis and triangulation process. Data collection techniques in question are 1) interviews, observation, documentation and visual materials. In this research, data analysis used is John W. Creswell model [7]. The steps include 1) organizing and preparing data for analysis, 2) reading or viewing all data, 3) the third stage is coding all data, 4) using the coding process to produce a description of the settings or people or categories or themes for analysis, 5) advancing how descriptions and themes will be represented in qualitative narratives, 4) making interpretations of results and finding qualitative research.

\section{RESULT AND DISCUSSION}

\section{A. Makassar Sombere and Smart City}

Smart city in Makassar City unites technology development (smart) with local wisdom (sombere'). The technology developed in Makassar City include Telkomsel 4G LTE service with $1800 \mathrm{MHz}$ frequency, electrocardiogram (ECG) and ultrasonography (USG), CCTV camera, alleyways application, war room facility, smart card and broadband network. In addition to these technology tools, there are still many technology tools that are and will be developed. One of them is Pete-Pete smart (car-based freight application). In general, the technology used in smart city is a modern and distinctive technology. The device is so advanced that it is called modern. The design is made up so it is called typical.

The value of local wisdom in question is sombere'. Sombere' is a local wisdom of Bugis and Makassar tribes. Sombere' means politeness to others. Sombere' is part of the past civilization of Bugis Makassar society which is again popularized now and in the future. Sombere' redesigned into a new civilization that became a special icon in the city of Makassar. In Indonesian, sombere' can be interpreted friendly. Therefore, the icon that was popularized in Makassar City is Makassar Sombere' and Smart City (Makassar City Friendly and Smart). A blend of technological tools with local culture in urban governance.
Currently the city of Makassar is developing various activities of sombere' and smart that lead to various sectors. In general, there are six dimension of sombere

, and smart city like smart economy, smart people, smart governance, smart mobility, smart environment, smart living. The real sombere and smart activities in question include:
1) Sombere' and smart governance
2) Sombere' and Smart Environment
3) Sombere' and smart public security
4) Sombere' and smart NTPD 112
5) Sombere' and smart transport
6) Sombere' and smart social
7) Sombere' and smart tourism
8) Sombere' and smart health care
9) Sombere' and smart card
10) Sombere' and smart learning
11) Sombere' and smart RT-RW

In initiation and implementation of Makassar Sombere' and Smart Governance, Makassar city government involves various parties. From the elements of local government covers all elements of the Regional Device Work Unit (SKPD) and Regional Leadership Council (Muspida). The central government elements are Ministry of Information and Communication (Menkominfo). The university elements include Hasanuddin University (Unhas), Ujung Pandang State Polytechnic (PNUP), STIMIK Dipanegara, University of Bosowa (Unibos) and Muhammadiyah University of Makassar (Unismuh). The elements of the company, PT. Telkom and PT. Telkomsel is involved in network development. As for the community, the city government of Makassar involves all elements of society who are members of RT / RW (Neighbourhood head and Head of Hamlets). In order to strengthen the role and function of each party, the city government of Makassar established Smart City Council of Makassar City. The members of Smart City Council of Makassar City are practitioners, academicians and society.

\section{B. Concept of Smart Governance}

The missions of governance in Makassar city are enhancement of locally-generated revenue, enhancement of ethos and performance of head of hamlets apparatus, enhancement of service in lower district, public service doorto -door, development of integrated public service in district area, modernization of public service and distribution, development of internet access in public sphere, enhancement of regional owned enterprises. Moreover, there are three goals of governance in Makassar city namely acceleration bureaucratic reform, enhancement of public service performance, enhancement capacity and performance of local government finance. Program in governance aspect hang over program of information and technology utilization, program of telecommunication development and program of communication and technology system development. 
Sombere' and smart governance is a top priority in the development of Makassar City to the world city. Sombere' and smart city in Makassar City is designed specifically to organize public affairs for the better. The goal is to realize the governance and governance of local government that is effective, efficient, communicative, and continue to improve the performance of bureaucracy through innovation and technology adoption that is integrated with local culture. The concept of smart governance in Makassar focuses on three aspects: public services, bureaucracy management and policy efficiency. In detail, the concept of sombere and smart governance in Makassar are:

\section{1) Public Service}

a) On-line and local-based administrative services. Example: Service using Mobile device in service complaint.

b) Accessibility of services by all levels of society. Examples: Easy access and convenient for use by the community, including disables.

c) Facilities and infrastructure of environmentally friendly services. Example: Available green open space, child friendly space and lactation room in every public service place.

d) Effective, efficient, proactive, integrative and transparent public services. Example: Birth certificate service before leaving the Hospital through Civil Registry officers.

\section{2) Bureauratic Management}

a) Fair-bureaucratic governance, accountability and transparency. Examples: e-planning system, e-budgeting, e-monev and others.

b) A clean bureaucracy, service and integrity. Example: Availability of finger scan in all government office in Makassar City, e-procurement.

c) Data Center is integrated to all government office in Makassar City. Example: Digital archiving in Big Data form.

d) Optimization of ICT in the management of bureaucratic management. Example: Land transportation management information system, monitoring the condition of the region.

\section{3) Efficiency of Public Policy}

a) Community involvement in public policy formulation. Example: Utilization of Musrenbang results as initial data and information in policy formulation. b) Transparency of public policy process. Example: Policy processes and results are accessible to all.

c) Public-based policy advocacy on line. Example: Availability of special teams in transfer of policy.

d) Media cooperation in public policy. Example: News and media review results are an ingredient in public policy analysis.

\section{CONCLUSION}

The concept of smart city governance in the city of Makassar brings the spirit sombere' (friendly) and smart to Makassar society and visitors. Concept combines the use of technology and the values of local wisdom. In its initiation and implementation, the city government of Makassar involves many parties consisting of practitioners and academics. In particular, the concept of smart city governance focuses on three aspects of public service, bureaucratic management and the efficiency of public policy.

\section{ACKNOWLEDGMENT}

The authors received financial support for the research from the Ministry of Research, Technology and Higher Education of Indonesia. We thank to all parties that help us in research project.

\section{REFERENCES}

[1] R. Goodspeed, Smart Cities: Moving Beyond Urban Cybernetics to Tackle Wicked Problems. Cambridge Journal of Regions, Economy and Society. Vol 8, pp. 79-92, 2015. Accessed on 5 March 2016 from Oxford Journals (doi:10.1093/cjres/rsu013).

[2] A. Sorensen, dan J. Okata, (ed). Megacities: Urban Form, Governance, and Sustainability. Tokyo: Springer. 2011

[3] L. Carvalho, Smart Cities from Scratch? A Socio-technical Perspective. Cambridge Journal of Regions, Economy and Society. Vol 8, pp. 43-60, 2015. Accessed on 5 March 2016 from Oxford Journals (doi:10.1093/cjres/rsu010).

[4] A. Glasmeier., dan S. Christopherson, Thinking about Smart Cities. Cambridge Journal of Regions, Economy and Society. Vol 8, pp. 3-12, 2015. Accessed on 5 March 2016 from Oxford Journals (doi:10.1093/cjres/rsu034).

[5] R. Kitchin, Making Sense of Smart Cities: Addressing Present Shortcomings. Cambridge Journal of Regions, Economy and Society. Vol 8, pp. 131-136, 2015. Accessed on 5 March 2016 from Oxford Journals (doi:10.1093/cjres/rsu027).

[6] T. Shelton, Zook, M., dan Wiig, L. The Actually Existing Smart City. Cambridge Journal of Regions, Economy and Society. Vol 8, pp. 13-25, 2015. Accessed on 5 March 2016 from Oxford Journals (doi:10.1093/cjres/rsu026).

[7] J.W Cresswell, Research Design: Qualitatif, Quantitatif, and Mixed Methods Approaches $4^{\text {th }}$ ed. USA: Sage Publications. 2014. 